\title{
Learning to Learn; Learning to Win: How to Succeed in the Simulated World of Model NATO
}

\author{
Andrey A. Meleshevich, National University of Kyiv-Mohyla Academy \\ Howard Tamashiro, Allegheny College
}

S imulations and role-playing exercises have been used effectively as a teaching device in all areas of political science and international relations. ${ }^{1}$ One such simulation, with 20 years of success, is the Model NATO Conference, currently sponsored annually in Washington, D.C., by Howard University and Kent State University's Center for International and Comparative Studies. ${ }^{2}$ Model NATO is an intercollegiate, competitive, and experiential learning exercise that models the decision-making and crisis management processes of NATO. Student delegations, representing different NATO membercountries, negotiate consensus agreements while promoting their often conflicting national interests. According to the Model NATO web site, this competition is designed to

- "Increase awareness of the role, organization and activities of NATO in the defense of shared democratic values;

- Highlight the major military-security and political issues facing NATO Member States;

- Generate understanding of the capabilities and constraints that shape the policies of NATO Member States in matters of collective defense;

Andrey A. Meleshevich is the dean of the School of Law and a professor of law and politics at the National University of Kyiv-Mohyla Academy in Ukraine. Formerly he taught and served as director of the International Studies Program at Allegheny College. He has published in the fields of institution-building in transitional countries, political parties, political consequences of electoral laws and executive-legislative arrangements, constitutional law, philosophy of law, and legal education. His e-mail address is ameleshe@ukma.kiev.va.

Howard Tamashiro is a professor of political science at Allegheny College. His research and teaching interests are U.S. foreign policy, defense and national security studies, politics and psychology of perception and propaganda, and moral and ethical aspects of war. His e-mail address is htamashi@allegheny.edu.
- Demonstrate patterns of cooperation and conflict that characterize intraNATO diplomacy;

- Highlight recent changes affecting NATO's security policies;

- Demonstrate the need for effective diplomatic, economic, and military cooperation in an unfolding crisis situation." 3

This paper discusses methods used by Allegheny College - a standard small liberal arts college and a four-time winner of the Best Delegation award at Model NATO - to enhance student learning. The paper also describes how student delegations can become more competitive in role-playing simulations, how Model NATO might strengthen a political science and international relations curriculum, and what long-term academic benefits might emerge from an extended record of Model NATO successes. The utility of these lessons and tools extends beyond Model NATO, and is applicable to other intercollegiate simulations and role-playing exercises.

\section{Model NATO's Procedural Framework ${ }^{4}$}

Model NATO is a four-day simulation held annually in late February or early March. About 20 schools from Canada and the United States send student delegations, ranging in size from five to 12 participants, to compete. Each delegation represents one or possibly two NATO member-countries on five simulated NATO committees (North Atlantic Council, Political Affairs Committee, Defense Planning Committee, Nuclear Planning Group, and Political-Military Steering Committee on Partnership for Peace). The goal for each delegation is to negotiate consensus on a variety of agenda issues while defending the national interests of one's assigned country. In addition, the Model NATO organizers introduce a surprise international crisis during the simulation to further test student coping skills.

At all times, whether in crafting agreements or managing emergencies, delegations must stay in character, that is, remain faithful to the countries they represent. On the first day of the exercise, each delegation visits the embassy of its assigned NATO country for briefings by embassy diplomats to help students stay in character. Over the five years that Allegheny College participated in the Model NATO conference, our experience at the French and Ukrainian Embassies was overwhelmingly positive. We are particularly grateful to Philipe Errera (political counselor at the French Embassy at the time) and Oleksander Potekhin (political counselor at the Ukrainian Embassy at the time) for providing invaluable assistance to our team and accepting our invitation to visit Allegheny College and meet with out students. Students consider embassy briefings and their meetings with diplomats as one of the highlights of the simulation. Following these briefings, the conference unfolds with a series of concurrent NATO committee meetings. Each committee debates agenda items provided by the Model NATO organizers, introduces new items, and drafts communiqués.

Committee negotiations and full immersion experiences continue past the formal meetings well into the evening. Some students report writing up to 12 draft communiqués before reaching committee consensus on an agenda item. Model NATO formally ends on the fourth day, after the North Atlantic Council's up-or-down votes on all submitted draft communiqués.

Model NATO's scheduling and procedural framework is time tested and works well. This is a definite plus, especially when compared with the work necessary to create one's own simulation from scratch. Further, the relatively small number of delegations in Model NATO ensures that all students will be engaged. Every student has an opportunity to debate issues and draft communiqués. In short, Model NATO's pedagogical return is excellent.

\section{Academic Merits of Model NATO}

What scholastic benefits accrue from the Model NATO simulation? Student role playing in a competitive context 
encourages participants to make connections and develop a depth of understanding that are not usually the focus of standard class lectures (Hertel and Millis 2002).

Over the past five years, Model NATO agenda items have reflected five broad themes: (1) new adjustment challenges and commitments facing NATO in the post-Cold War era's shifting nature of the alliance; (2) NATO enlargement and its geopolitical consequences; (3) the proper role of the U.S. within NATO (sometimes referred to as the "AtlanticistContinentalist" debate); (4) NATO/ European Union relations; and (5) international crisis management and peace-support operations.

As suggested by this thematic list, Model NATO is not a narrow military competition. Since the end of the Cold War, NATO's agenda has broadened significantly, so that a surprisingly increasing number of NATO programs are largely nonmilitary in character (e.g., the Istanbul Initiative, Mediterranean Dialogue, and Euro-Atlantic Partnership Council). This means students must study and be well versed in a wide array of political, diplomatic, and economic issues that extend beyond traditional military alliance concerns. For example, the 2005 Model NATO agenda included such topics as European Union-NATO relations, NATO-Russia relations, and NATO-Ukraine cooperation, as well as more traditional military subjects like WMD nonproliferation programs and global terrorism. If students fail to develop this breadth of knowledge, they risk being dominated or marginalized in the Model NATO competition.

Further, many NATO agenda items are connected to specific programs. For example, European-NATO relations are increasingly influenced by the European Union's European Security and Defense Program (ESDP) and NATO's Defense Capabilities Initiative (DCI). In order to compete successfully, students need both broad issue area understanding and specific programmatic knowledge in order to negotiate agreements consistent with the interests of other NATO members. Allegheny students have won the Model NATO competition by integrating their expertise across different issues to elaborate broad team strategies and objectives that are realized through the creating and negotiating of concrete policy proposals. These proposals emerge in the form of communiqués, drafted by the students. Pedagogically, the breadth and depth of knowledge promoted by Model NATO make it an excellent vehicle for studying European security, broadly defined.
Besides mastering NATO-related issues and programs, students must know the country they represent and learn its policy-relevant characteristics. Examples may include the following:

- How internal political issues influence foreign policy in one's assigned country. For instance, when representing France in the Model NATO competition, students learned the policy implications of presidential-prime minister splits during the cohabitation period from 1997-2002.

- How foreign policy country profiles influence national perceptions and behavior. For example, Greece has a reputation as a spoiler country in NATO because it frequently uses its veto power for bargaining purposes. Or Canada's peacekeeping reputation, which, over time, has seriously degraded Canadian combat capabilities.

- How certain issues and geographic proximity produce alliance patterns (e.g., the Spain-France-Italy axis on Mediterranean issues; Visegrad countries in Eastern Europe). In Model NATO, sometimes even committee seating arrangements can influence cooperation patterns among student delegations - students sitting together may be more likely to cooperate than when they are seated apart.

- How power differentials might be exploited in NATO politics. For instance, on certain issues, small countries might be mobilized against large ones.

In the competitive, role-playing context of Model NATO, students learn quickly that pursuing narrow, personal agendas almost always fail. Seeing international problems from multiple viewpoints and fashioning consensus agreements are the keys to success. Knowledge of issues, programs, and country characteristics make the negotiating of common group agendas and agreements possible.

Shifting our focus from the inner workings of Model NATO to broader scholastic issues, we note that the simulation can satisfy a curriculum-enhancing function in at least three important ways. First, because of Model NATO's issuearea breadth, it can serve as a capstone experience for the international relations and comparative politics subfields in most political science curricula. For example, Model NATO is a natural arena for students seeking to apply their knowledge of national security and for- eign policy courses on one hand, or European and post-Soviet courses on the other. Second, because of Model NATO's emphasis on writing, negotiating, and debating, it can serve as a culminating experience in an applied communications program. Finally, Model NATO's academic rigor makes it suitable to be the centerpiece of an honors seminar for advanced political science or international studies students.

\section{Student Preparation}

Schools participating in the Model NATO simulation recruit and prepare their students in different ways. Some schools recruit for open enrollment, general international relations classes; others select students from college-wide political science clubs. In 2001-2005, Allegheny College drew its students from an upper division course on European security that requires all enrollees to enter the Model NATO competition.

Most Allegheny participants are international studies, who fared particularly well in the competition, or political science majors. However, prior international or political course work, while useful, is not necessary for Model NATO success. English, modern language, and environmental studies majors have performed generally well in past competitions. Proper motivation is more important than prior course work.

In particular, student willingness to collaborate is essential for adequate preparation. The complexity of the Model NATO agenda means that no single individual can master everything. Expertise must be shared. Within a delegation, students research assigned topics, share their findings in position papers, and construct negotiation strategies and draft communiqués that will appeal to other NATO country-teams. For example, in preparing for the 2005 NATO competition, the Allegheny College delegation created a NATO initiative, similar to the successful Partnership for Peace program in Eastern Europe, ${ }^{5}$ to promote regional commercial and counterterrorism cooperation in the greater Middle East.

This collaborative learning team approach is also used during the competition. First, Allegheny's two-person student teams work within each NATO committee to create alliances with other schools. Second, these student teams coordinate their efforts with other teams across committees. As a learning device, such a team emphasis helps students acquire speaking experience, bargaining practice, conflict management experience, and group management skills that are neglected in traditional lecture-based 
classes. In the process, students develop a greater appreciation for the practical difficulties and complexities of alliance politics.

Another important part of preparation is the identifying of course materials. In general, finding suitable materials is not difficult since the number of available NATO-related sources is huge. Valuable, easily accessible sources include newspaper articles, web sites, journal articles, government documents, books, and reference sources.

Since timeliness of one's information is crucial in Model NATO, student exposure to the elite press such as the Wall Street Journal, New York Times, Washington Post, Financial Times, and Economist is a must. Further, students with relevant foreign language fluency may be given extra credit for providing the class with NATOrelated news summaries from European sources (e.g., Le Monde, Der Spiegel).

NATO and European Union-related web sites are also valuable sources, especially for information on specific policies and programs (e.g., the official NATO site is www.nato.int; on the European Union, see www.europa.eu.int). Embassies are another important source for upto-date policy documents. Also, editorials and other opinion pieces should not be overlooked. Allegheny students found these useful for getting a feel for foreign rhetoric and styles of arguing.

The NATO Handbook, distributed by the Model NATO sponsors to all participating schools, provides a clear reference for understanding the complex NATO system. Other useful sources on NATOrelated topics include National Interest, Foreign Affairs, Orbis, Parameters, and Armed Forces Journal International. Students should also be encouraged to watch $\mathrm{CNN}$ or listen to the $\mathrm{BBC}$ for latebreaking news.

No matter how diligent their preparation, however, students cannot master everything. Model NATO rules allow for deception. Students may fabricate and misrepresent to disguise their knowledge gaps or to gain tactical advantage in the competition. But, in general, Allegheny College discouraged such trickery among its students. Any transitory, negotiating advantage purchased by subterfuge is not worth the inevitable loss of credibility and trust.

Another, related issue concerns the use of the Model NATO rules of procedure for bargaining advantage. A delegation can easily use the rules to interrupt committee discussions or delay votes on resolutions. Again, Allegheny students were discouraged from such actions. Under normal circumstances, gaining resolution agreement is difficult. Delaying commit- tee work via procedural chicanery will annoy other delegations and stigmatize one's delegation as obstructionist.

On the other hand, familiarity with the rules of procedure is important to avoid being victimized. For example, during the 2003 Model NATO competition, an Allegheny student left a committee meeting for a few minutes, which allowed opposing delegations to pass a quick agenda change unfavorable to the country our students represented. The absent student was unaware such an agenda change was permissible.

Allegheny faculty schedule about two class hours for reviewing Model NATO's rules of procedure. Brief in-class oral exercises are useful. For example, each student is asked for the appropriate rule response in a committee scenario (e.g., "You wish to question a speaker. What do you do?"). Video taping a Model NATO committee meeting for class review is also recommended.

\section{Faculty Advisor Roles}

Since the Model NATO program is an active-learning, student-centered, competitive enterprise, faculty advisors must be prepared to act as teachers, collaborators, and advisors. During the first, teaching stage of preparation, faculty must provide background information on NATO, an adopted country, European/EU affairs, and the Model NATO competition. At Allegheny, students can compete in Model NATO just once. Since each year's student group is a rookie delegation, background preparation is vital. The key task for the advisor is to provide context and perspective. Information must be selective, designed to give students the big picture.

At Allegheny, contextual material is presented in a special course entitled European Security and NATO. Class experience has revealed the following teaching points. Students find lectures taking a strategic, geographical, or historical approach especially useful. When introducing a strategic or historical context, use a story format whenever possible. ${ }^{6}$ Emphasize the language of intentions, plans, perceptions, goals, successes, and failures when explaining a country's behavior. Avoid laundry lists of events or lengthy tours through organizational charts. If one provides a clear, uncluttered background, students will be able to research and use surprisingly technical and sophisticated policy material on their own.

Also, during the teaching stage of student preparation, the faculty advisors should describe the Model NATO competition, explaining its challenges and methods for overcoming them. In this way, students will acquire an added sense of purpose when researching and learning NATO fundamentals and the nature of alliance politics. For example, emphasizing NATO's principle of consensus decision making alerts students early on that they must learn the foreign policy goals of all NATO members, not just the goals of a few close friends. Sometimes the lessons of Model NATO are more mundane. For instance, the advantage of controlling communiqué drafts suggests the importance of bringing laptop computers to the competition.

In the second, collaborating stage of preparation, students, having been given NATO committee and issue assignments, assume greater initiative in finding and sharing materials with each other. ${ }^{7}$ Students become resource experts in their assigned areas. Faculty advisors might suggest additional resource materials and breaking news items. However, at this stage, the advisor's role grows less intrusive and more intermittent as the students increasingly assume the responsibilities of gathering, analyzing, and distributing information. Each student presents a short briefing paper on two or three Model NATO agenda topics that includes all major talking points. These papers are distributed to everyone and used as resource material at the Model NATO competition.

Students also collectively design program proposals and diplomatic team strategies that might be used during the competition. Many of these proposals might not be used, but forcing students to plan in an integrated fashion promotes teamwork, encourages alternative thinking, and gives everyone a sense of ownership over the class planning.

During this collaborative phase, faculty evaluation of the students also begins. While the students work in pairs (one pair per Model NATO committee), the faculty advisors note how the work is distributed within each pair so the students can be evaluated individually.

In the final, advising stage, faculty advisors offer clarification and advice during the Model NATO competition. However, the initiative and control rests with the students. Because the Mode NATO competition is a free-play simulation that unfolds simultaneously across five committees and involves private behind-the-scenes negotiating, faculty cannot exercise the control of a football coach calling plays.

From a pedagogical view, students benefit from this freedom because they must use their own problem-solving ingenuity. Faculty advisors benefit too because they have the freedom to observe and evaluate students without distractions. 


\section{Grading}

While teamwork is emphasized in Allegheny's Model NATO course, students are evaluated on the basis of their individual performances. No team grades are given. Each student's briefing paper, oral class performance, and Model NATO conference participation is assessed. In a few borderline cases, a final optional oral exam is offered to students at the end of the semester. In general, we believe individual grades can promote a greater motivation to work.

\section{Post Competition Debriefing, Outcomes, and Evaluations}

Following the Model NATO competition, students are given many opportunities to evaluate their learning experiences. They participate in a threehour debriefing session, write a five-page review of their competition experiences, and complete a course evaluation at the end of the semester. This feedback is used to improve Allegheny's Model NATO program.

Basically, students describe how the Model NATO course compares with other Allegheny courses, what benefits were gained, what improvements are needed, and how competing schools performed.

Students overwhelmingly praise their Model NATO experience. Some typical student remarks include:

- "We learned to work as a team, to achieve a common goal through hard work, determination, and perseverance."

- "European Security and NATO (Model NATO) was an excellent class. Not only did the class prepare me well for the NATO summit, but it also gave me a vast amount of knowledge I have never come close to achieving in any other class."
- "This class was both one of the most taxing and one of the most rewarding experiences I have had while at Allegheny."

- "Of all the classes I have taken here at Allegheny College, Political Science 433 (Model NATO) ranks as quite possibly the best class I have been enrolled in. This is because it provides hands on experience. It does not matter how much one reads about government issues and structure; you cannot fully understand it until you take part in it."

- "When at the conference I found in myself 'people' skills that I did not know that I had, I was able to move from circle to circle with ease. I changed the level of detail I would use depending on the delegates that I talked to."

- "Overall, this was one of the most valuable classes I've had at Allegheny. It helped in all areas of oral and written communication, and interpersonal relations."

- "The class is, hands down, the best class I have ever taken, here at Allegheny or elsewhere."

Students also offered the following, noteworthy lessons learned from their Model NATO experience:

- Diplomatic obstruction is easier to accomplish than consensus building.

- Patience is vital in diplomatic negotiations.

- Understanding the historical background of issues is instrumental for planning and calculating outcomes.

- Knowing the history of a country provides important clues about its future behavior.

- Political priorities can change rapidly and in unexpected ways during an international crisis.

- Maintaining communications with all parties is a vital diplomatic task.
- Seeing issues from the perspective of others is important in diplomatic negotiating.

These student remarks suggest the Model NATO competition captures important attributes found in real world alliance politics. Further, students see specific knowledge benefits from the simulation and value this knowledge learned.

Besides academic benefits, students frequently mentioned certain social benefits of Model NATO. In particular, they enjoyed traveling to Washington, D.C., visiting foreign embassies, participating in a national competition, and socializing with students from other schools.

A final noteworthy outcome of Model NATO is the extraordinary student enthusiasm generated by winning four consecutive Best Delegation titles (2002-05). This scholastic record produced a level of student excitement usually reserved for athletics. Despite the heavy class workload, Allegheny students have begun doing things beyond the course requirements. For example, prior to the 2005 competition, students, on their own initiative, created a Model NATO web site with links to relevant news items. And veteran students from earlier competitions volunteered their time to coach upcoming student delegations.

Each year's students are motivated by the achievement of the previous year's class. Each year's victory tells the next class that victory is possible again. In short, besides giving students a forum to display their expertise, Model NATO offers them the opportunity to establish a tradition of scholastic excellence. A teacher could not reasonably ask for more than this.

\section{Notes}

1. For a readable primer on using simulations for professional and college level teaching, see Hertel and Millis (2002). Starkey and Blake (2001) offer a brief overview on the use of simulations in international relations education. Publications that present work on international relations simulations include Simulation and Gaming, International Negotiation, and International Studies Perspectives (formerly International Studies Notes).

2. To participate in Model NATO, contact Dr. Michael Nwanze, Department of Political Science, Howard University, Washington, D.C. 20059; or Dr. Mark Rubin, Center for Inter- national and Comparative Studies, Kent State University, Kent, OH 44242.

3. http://dept.kent.edu/cicp/natoconference/ objectives.htm.

4. The Model NATO rules described here apply to the $2002-05$ period. From time to time, some procedural details might be modified. However, the basic framework, as described in this article, remains intact.

5. A NATO program begun in 1994, Partnership for Peace was designed to promote cooperation and trust between the NATO countries and the former Communist bloc nations.
6. Schank (1991) and Schank and Morson (1995) argue that human memory is organized as a storytelling process, and people learn effectively by hearing stories. While we do not necessarily endorse the cognitive theories of Schank and Morson, we do agree students find story-like narratives appealing and frequently easier to remember than material presented in other formats.

7. For the advantages of collaborative learning as a teaching strategy, see Kagan and Kagan (1999). 


\section{References}

Hertel, John P., and Barbara Millis. 2002. Using Simulations to Promote Learning in Higher Education. Sterling, VA: Stylus Publishing.

Kagan, Spencer, and Miguel Kagan. 1999. "The Structural Approach: Six Keys to Cooperative Learning." In Handbook of Cooperative
Learning Methods, ed. Sharan Sholomo. Westport, CT: Praeger.

Schank, Roger C. 1991. Tell Me a Story: A New Look at Real and Artificial Memory. New York, NY: Atheneum Publishers.

Schank, Roger, and Gary Saul Morson. 1995. Tell Me a Story: Narrative and Intelligence
(Rethinking Theory). Evanston, IL: Northwestern University Press.

Starkey, Brigid, and Elizabeth Blake. 2001.

"Simulation in International Relations Education." Simulation and Gaming 32 (December): $537-51$. 